\title{
Editorial
}

\section{Behind and beyond the gatekeepers' transformation}

\author{
Grace Wangge ${ }^{1,2}$ \\ ${ }^{1}$ Editor of Medical Journal of Indonesia \\ 2 Departement of Community Medicine, Faculty of Medicine Universitas Indonesia, Jakarta, Indonesia
}

Since 2014, Indonesia implements the universal health coverage (UHC) as part of the country health care reform. Despite of the political reasoning behind it, the UHC itself is a long due realization from the 2004 social insurance law that aim to improve health access of the country's 200 million citizen. UHC is also a part of the United Nations Sustainable Development Goals that all UN Member States, including Indonesia, have agreed to achieve by 2030 .

One of the key World Health Organization (WHO) recommendation for a successful implementation of UHC is strengthening of the primary health care. ${ }^{1}$ This recommendation appears to contradict the major direction of medical science development towards Nano and genomic technology. However, real world evidence clearly indicates that the strengthening of primary care, especially in middle and low income countries, succeeds in reducing morbidity and mortality rates. In a 2003 study, data from 42 countries worldwide showed that six million infant mortalities could be prevented yearly due to effective primary care service. ${ }^{2}$ The number is equated to 100 football stadiums of full of children. ${ }^{3}$ More success stories of primary care strengthening in developing countries were widely described in reports and publications. ${ }^{3,4}$

The terms primary health care, primary care, general practice and family medicine are often used interchangeably. It usually defines as initial contact of patient with health care professionals, hence the term "gatekeeper". Despite of its noble meaning, the term itself have been connoted differently among medical practitioners. In the analogy of a football match as a health system, a gatekeeper considered as someone who has a role to assure that only certain people can enter the arena. The gatekeeper has no particular authority in determining who can stay in the arena, nor has the opportunity to watch the whole match fully. The notion of the role of gate keeper is widely embraced not only by other specialists, but also by primary care doctors themselves. This misconception has decreased the gatekeepers' self-confidence and discourage them to develop their primary care skill.

In the 1978 declaration of Alma-Ata, instead of the traditional approach of medical service, the primary care should embrace the principles of social justice, equity, self-reliance, appropriate technology, decentralization, community involvement, intersectoral collaboration, and affordable cost. ${ }^{5}$ The declaration clearly demands primary care doctors to attain role beyond a bouncer in their country health system.

In this issue of Medical Journal of Indonesia, Werdhani $^{6}$ highlights the important role of primary care doctors as a manager of patient's case management. The author described in her article, the ideas how such leadership capability can be developed within the primary care workplace. In the same nuance, Taher describes how primary care have a long standing history not just as the provider of quality and equitable services for the community, but has established themselves in the root of genomic medicine. Tahir highlights the opportunity of primary health care doctors to contribute better to medical world as both public health specialist and basic-science scientists.

The high expectations for the primary care emphasize the need for improvement in the primary care doctors' capabilities. In their systematic review of postgraduate training for primary care physicians, Widyahening et $\mathrm{al}^{7}$ describe the postgraduate education for primary care physicians exists in 62 (86\%) in UHC-attaining countries worldwide. These postgraduate training was established as part of implementation of UHC in $11(18 \%)$ countries. These facts are not surprising, as investment in primary health care workforce is 
recommended by WHO as a cost-effective measure in improving health care services, provided it is supported by good governance, comprehensive facilities, sufficient supply of medicine and information technology systems. ${ }^{8}$

Those evidence exclaim that despite of the long ongoing debates on whether or not Indonesia need a formal postgraduate education for primary care doctors, strengthening of primary care is currently inevitable. These efforts will surely, not only focus in transformation of the gatekeepers, but more importantly requires a reverse way of thinking from the traditional approach of top-down health service. The latest could be the hardest challenge for health care reformists in Indonesia. All stakeholders in the end must remember that the goal of the health care system is to ensure the health for all citizens, thus any effort taken in the reformation are merely a means, not an end.

\section{REFERENCES}

1. WHO | Universal health coverage (UHC) [Internet]. WHO. World Health Organization; 2016 [cited 2017 Jun
29]. Available from: http://www.who.int/mediacentre/ factsheets/fs395/en/.

2. Jones G, Steketee RW, Black RE, Bhutta ZA, Morris SS, Bellagio Child Survival Study Group L. How many child deaths can we prevent this year? Lancet (London, England) [Internet]. [update Jul 2003; cited 2017 Jun];362(9377):65-71. Available from: http://www. ncbi.nlm.nih.gov/pubmed/12853204.

3. Mossman K, Bhattacharyya O, McGahan A, Mitchell W. Expanding the Reach of Primary Care in Developing Countries.pdf. Harvard business review [Internet]. 2017 Jun; Available from: https://hbrorg/2017/06/expandingthe-reach-of-primary-care-in-developing-countries.

4. Atun R. What are the advantages and disadvantages of restructuring a health care system to be more focused on primary care services? World Heal Organ Off Eur [Internet]. 2004; (January):18. Available from: http://www.euro.who.int/_data/assets/pdf_ file/0004/74704/E82997.pdf.

5. Beard TC, Redmond S. Declaration of Alma-Ata. Lancet. 1979;313(8109):217-8.

6. Werdhani RA. Leadership in doctor-patient relationship: Implementation on patient's case management in primary care. Med J Indones. 2017;6:158-66.

7. Widyahening IS, Tanoto R, Rinawan F, Setiawati EP, Leopando ZE. Does the establishment of universal health coverage drive the foundation of postgraduate education for primary care physicians?. Med J Indones. 2017;6:141-51.

8. WHO. The world health report: health systems financing: the path to universal coverage. 2010.

pISSN: 0853-1773 • eISSN: 2252-8083 • https://doi.org/10.13181/mji.v26i2.2130 • Med J Indones. 2017;26:81-2

Corresponding author: Grace Wangge, gwangge@gmail.com

Copyright @ 2017 Authors. This is an open access article distributed under the terms of the Creative Commons Attribution-NonCommercial 4.0 International License (http://creativecommons.org/licenses/by-nc/4.0/), which permits unrestricted non-commercial use, distribution, and reproduction in any medium, provided the original author and source are properly cited. 